$16^{\text {th }}$ International Conference on

AEROSPACE SCIENCES \& AVIATION TECHNOLOGY,

ASAT - 16 - May 26 - 28, 2015, E-Mail: asat@ mtc.edu.eg

Military Technical College, Kobry Elkobbah, Cairo, Egypt

Tel : +(202) 24025292 - 24036138, Fax: +(202) 22621908

\title{
Structural Performance of Ferrocement Tanks under Pressure Loads
}

Y. Shaheen ${ }^{\mathrm{a}}$, F. Aboul-Ella ${ }^{\mathrm{a}}$, B. Eltaly ${ }^{\mathrm{b}}$ and M. Kameel ${ }^{\mathrm{c}}$

${ }^{a}$ Professor, Civil Engineering Department, Faculty of Engineering, Minoufia University, Egypt

${ }^{b}$ Lecturer, Civil Engineering Department, Faculty of Engineering, Minoufia University, Egypt.

${ }^{c} \mathrm{PhD}$ student, Civil Engineering Department, Faculty of Engineering, Minoufia University, Egypt.

\begin{abstract}
An experimental program was designed in the current work to examine the structural behavior of ferrocement tank under static pressure loads. The experimental program consists of construction and testing of two ferrocemnt tanks having the dimensions of $800 \mathrm{~mm}$ width, $800 \mathrm{~mm}$ length and $400 \mathrm{~mm}$ wall height. The wall and footing thickness is $40 \mathrm{~mm}$ and 70 $\mathrm{mm}$; respectively. The two tanks were different in the type of reinforcements; welded and expanded wire meshes. The structural performances of the all tested tanks in terms of strength, cracking behavior and energy absorption were investigated. The results of the experimental tests indicated that tank reinforced with two layers of welded wire meshes has the highest first crack and ultimate load and it has the maximum energy absorption.
\end{abstract}

Keywords: Ferrocement; Ground tank; Ferrocement tank; Pressure load; Structural behavior.

\section{Introduction}

Water tanks are considered a very important structure regarding to their responsibility of storage water without any losses. These structures come in a variety of configurations. They may be elevated, ground supported or under-ground tanks. The ground supported tanks consists of the vessel. The vessel comes in a variety of geometric shapes such as rectangular, cylinders, spheres, cones or a combination of any of these geometric shapes.

Ferrocement is a highly versatile form of reinforced concrete commonly constructed of hydraulic cement mortar reinforced with metal and non-metal wire meshes; woven wire mesh, welded wire mesh, expanded metal mesh and fiber. Ferrocement can be constructed with a minimum of skilled labor and utilizes readily available materials. It has found wide-ranging applications in many countries. Its applications include aqueducts, boats, buildings, bus shelters, bridge decks, food and water storage containers, irrigation structures, retaining walls, sculptures, roofing, repairing and traffic-caution signboards. From previous studies, it can be concluded that ferrocement has a considerably higher bond area or specific surface than conventional reinforcement and ferrocement beam has better crack control and the smaller crack width than reinforced concrete ${ }^{(1-19)}$. 
In many countries, ferrocement tanks are used for the collection and storage of water for drinking, washing, animal use and irrigation. Ferrocement tanks vary in capacity, size, and shape and they may be built by hand. They are usually cheaper than steel tanks or fiber reinforced plastic because of the high manufacturing cost of the other materials. Also ferrocement tanks have better corrosion resistance and they have lower maintenance costs than steel tanks. In ferrocement tank, large amounts of small diameter meshes uniformly distributed within the concrete section are used these lead to provide a very efficient and simple form of crack control ${ }^{(20-28)}$. Additionally a number of researches investigated a method for strengthening and repairing of concrete reinforcement tanks that depend on using ferrocement technic (Fahmy and Shaheen ${ }^{(29)}$ and Fahmy et al ${ }^{(30)}$ ). From their results, it was concluded that this method of construction provides durable and high strength water tanks.

The main objective of the current research is studying the performance of ferrocement tanks under static pressure. Also this work presents the effect of the reinforcement system on the mechanical properties of the ferrocement tanks. The matrix was designed to have high strength, low water to binder ratio, flow characteristics and high durability. In the current paper, two ferrocement tanks different in the reinforcement system were designed, constructed and tested under static pressure. The static pressure was occurred using well impact sand. The tank was filled with the sand. The well compacted sand was loaded by uniform loads. These loads were created by inserting thick steel plate on the top surface of the sand and an increasing concentrated load was applied on the thick steel plate.

\section{Specimen Details}

The current experimental program concluded casting and testing two types of ferrocement tanks. The two tanks (RT1 and RT2) had the same dimensions and different in the system of the reinforcement as presented in Table 1. Their internal dimensions are $800 \mathrm{~mm} \times 800 \mathrm{~mm} \times$ $400 \mathrm{~mm}$ and their wall and footing thickness are $40 \mathrm{~mm}$ and $70 \mathrm{~mm}$; respectively as shown in Fig.1.

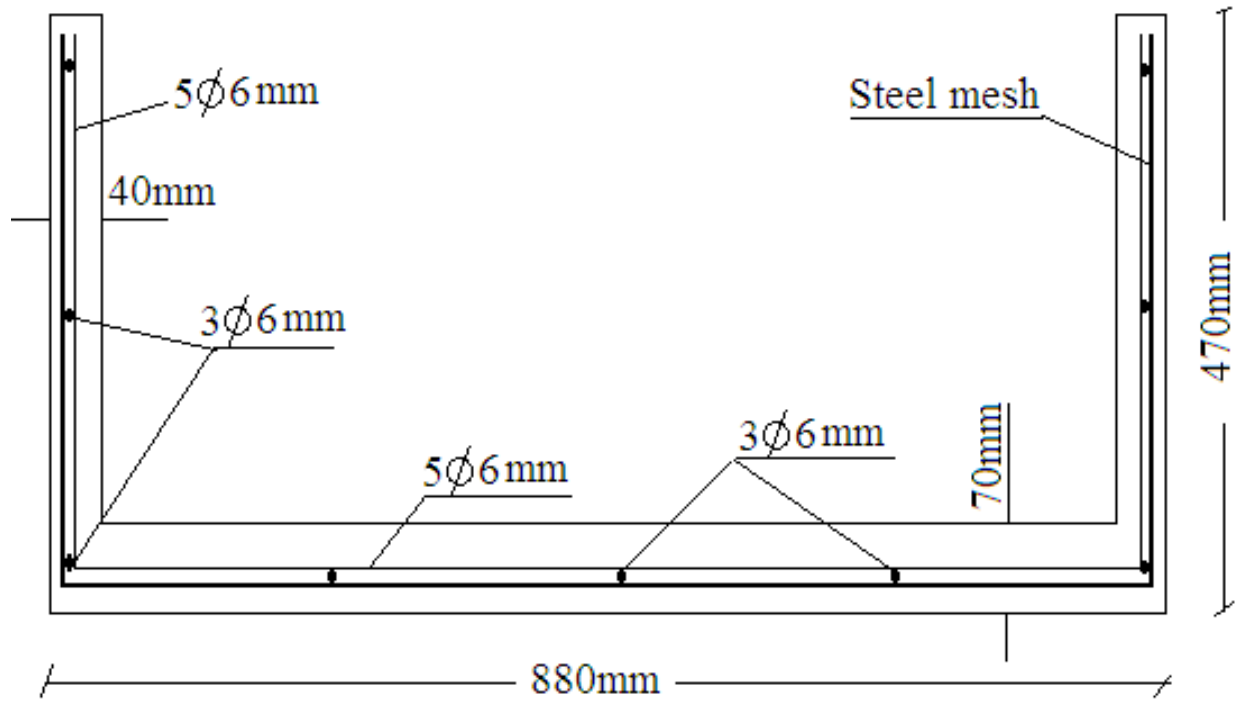

Fig.1 Specimen Details 
Table 1 Studied tanks details

\begin{tabular}{|c|c|c|c|c|c|c|c|}
\hline \multirow{3}{*}{ 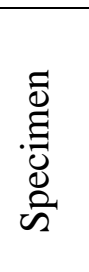 } & \multirow{3}{*}{ 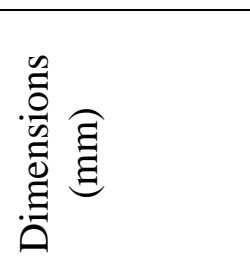 } & \multicolumn{2}{|c|}{$\begin{array}{c}\text { Thickness } \\
(\mathrm{mm})\end{array}$} & \multicolumn{4}{|c|}{ Reinforcement } \\
\hline & & \multirow[b]{2}{*}{$\overline{\bar{\sigma}}$} & \multirow[b]{2}{*}{$\begin{array}{l}\stackrel{\infty}{0} \\
. \\
0 \\
0 \\
0\end{array}$} & \multicolumn{2}{|c|}{ Wire meshes } & \multicolumn{2}{|r|}{ Steel bars } \\
\hline & & & & Welded & Expanded & Wall & Footing \\
\hline RT1 & $800 \times 800 \times 400$ & 0 & 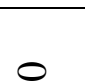 & One layer & One layer & $5 \mathrm{~V}+3 \mathrm{H}$ & $5 \emptyset 6 \mathrm{~mm} \quad$ (main) \\
\hline RT2 & & & & Four layers & - & & \\
\hline
\end{tabular}

\section{Components of Mortar Matrix}

The materials used in the experimental program were ordinary Portland cement and sand. The Ordinary Portland Cement used was provided from Suez Cement Factory and it is fresh, has uniform consistency and free from lumps and foreign matter. Its chemical and physical properties of the cement were compared with the Egyptian specifications ${ }^{(31)}$. The used fine aggregate was clean desert sand (natural siliceous sand) and its sieve analysis results are presented in Table 2. To increase the strength of the mortar as possible, condensed silica fume was used as a partial replacement of the cement (10\% by weight of cement). It was delivered in a powder form and with a gray color. The chemical composition of silica fume is given in Table 3. To control of ferrocement cracking due to drying shrinkage and thermal expansion/contraction and to lower concrete permeability, polypropylene fibers was added to the mortar mix (see Fig. 2). Polypropylene fiber e 300 fiber was added as $900 \mathrm{gm} . / \mathrm{m}^{3}$ of the mortar mix and its chemical and physical properties are shown in Table 4. Also Viscocrete5930 obtained from Sika-Egypt Company for Construction with 1.0\% by weight of cement content was used to increase flow ability of the mortar. Fresh drinking water and free from impurities was used for mixing and curing of the test specimens.

Table 2 Sieve analysis results for the used sand

\begin{tabular}{cccccc}
\hline Sieve Size $(\mathrm{mm})$ & 2.83 & 1.4 & 0.7 & 0.35 & 0.15 \\
\hline$\%$ Passing by weight & 90.9 & 79 & 68 & 17 & 2 \\
\hline Limits of (E.E.S.) & $100-85$ & $100-75$ & $80-60$ & $30-10$ & $10-0$ \\
\hline
\end{tabular}

Table 3 Chemical composition of silica fume

\begin{tabular}{cc}
\hline Chemical & Weight percent (\%) \\
\hline $\mathrm{SiO} 2$ & $92-94$ \\
\hline Carbon & $3-5$ \\
\hline $\mathrm{Fe} 2 \mathrm{O} 3$ & $0.1-0.5$ \\
\hline $\mathrm{CaO}$ & $0.1-0.15$ \\
\hline $\mathrm{AL} 2 \mathrm{O} 3$ & $0.2-0.3$ \\
\hline $\mathrm{MgO}$ & $0.1-0.2$ \\
\hline $\mathrm{MnO}$ & 0.008 \\
\hline $\mathrm{K} 2 \mathrm{O}$ & 0.1 \\
\hline $\mathrm{Na} 2 \mathrm{O}$ & 0.1 \\
\hline
\end{tabular}


Table 4 Chemical and physical properties of polypropylene fibers

\begin{tabular}{cc}
\hline Absorption & Nil \\
\hline Specific gravity & 0.91 \\
\hline Fiber length & Single cut lengths \\
\hline Electrical conductivity & Low \\
\hline Acid \& salt resistance & High \\
\hline Melt point & $324^{\circ} \mathrm{F}\left(162^{\circ} \mathrm{C}\right)$ \\
\hline Thermal conductivity & Low \\
\hline Ignition point & $1100^{\circ} \mathrm{F}\left(593^{\circ} \mathrm{C}\right)$ \\
\hline Alkali resistance & Alkali proof
\end{tabular}

\section{Wire Meshes}

Table 5 Dimensions and mechanical properties of wire meshes

\begin{tabular}{ccccccc}
\hline Mesh Type & $\begin{array}{c}\text { Opening size } \\
(\mathrm{mm})\end{array}$ & $\begin{array}{c}\text { Weight } \\
\left(\mathrm{N} / \mathrm{m}^{2}\right)\end{array}$ & $\begin{array}{c}\text { Diameter } \\
(\mathrm{mm})\end{array}$ & $\begin{array}{c}\mathrm{F}_{\mathrm{y}} \\
(\mathrm{Mpa})\end{array}$ & $\begin{array}{c}\mathrm{F}_{\mathrm{u}} \\
(\mathrm{Mpa})\end{array}$ & $\begin{array}{c}\text { Modules of } \\
\text { elasticity } \\
(\mathrm{GPa})\end{array}$ \\
\hline Expanded mesh & $19.7 \times 43.7 \pm 0.3$ & 20 & $1.5 \times 2.1$ & 250 & 350 & 120 \\
\hline Welded mesh & $12 \times 12 \pm 0.3$ & 4.5 & 0.72 & 400 & 600 & 170 \\
\hline
\end{tabular}

Two types of steel wire meshes; welded and expanded wire meshes were used as shown in Fig. 2. Their dimensions are indicated in Table 5. To estimate the characteristics of the steel wire meshes used under tensile load, three samples of each type of the meshes were tested by the standard testing machine as shown in Fig. 3. The specification and the mechanical properties of the steel meshes are illustrated and shown in Table 5.

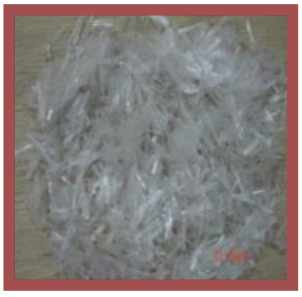

a) Polypropylene fibers

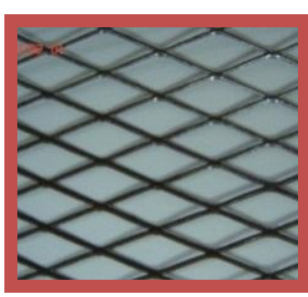

b) Expanded mesh

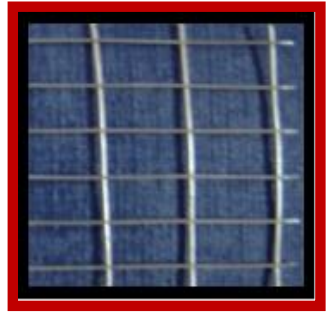

c) Welded mesh

Fig. 2 Used fibers and reinforcement steel wire meshes 


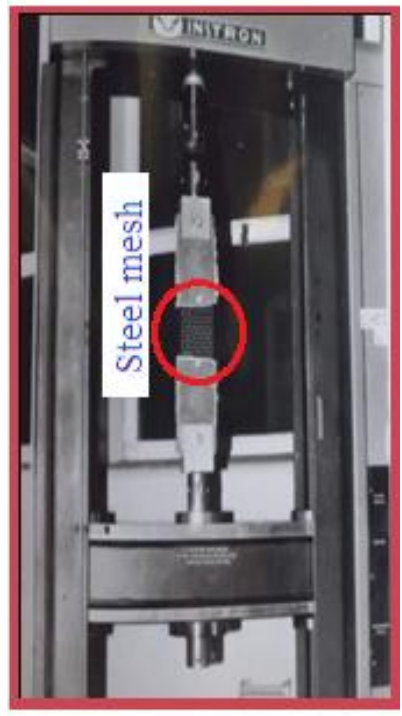

Fig. 3 Wire mesh tensile test

\section{Design of Ferrocement Mixture}

Six mortar mixes were designed and tested to select the best proportions of the ferrocement constituent's materials. Table 6 shows the composition of the mortar matrix of the tested mixtures. Compression tests were carried out on $100 \times 100 \times 100 \mathrm{~mm}$ cubes according to the Egyptian Standard Specifications ${ }^{(31)}$ by using $2000 \mathrm{kN}$ hydraulic compression-testing machine capacity. Table 7 shows the compressive strength of ferrocement mortar for the six mortars mixes after 3, 7 and 28 days; respectively. From these test results, it can be concluded that the best mortar mix is Mix\#6. Three cylinders 150x300 mm were cast and were laid horizontally in the compression testing machine to determine the indirect splitting tensile strength of chosen mortar mix (Mix\#6) after 28 days. The tensile splitting strength is considered as 3.9 Mpa.

Table 6 Composition of the tested mortar matrix

\begin{tabular}{|c|c|c|c|c|c|}
\hline Mix No. & $\mathrm{S} / \mathrm{C}$ & $\mathrm{W} / \mathrm{C}$ & S.F & $\begin{array}{l}\text { Fibers } \\
\mathrm{gm} . / \mathrm{m}^{3}\end{array}$ & Super-plasticizer \\
\hline 1 & \multirow{3}{*}{1.8} & \multirow{6}{*}{0.35} & ---- & ---- & \multirow{6}{*}{$1 \%$} \\
\hline 2 & & & $10 \%$ & $\begin{array}{ll}--- \\
\end{array}$ & \\
\hline 3 & & & $10 \%$ & 900 & \\
\hline 4 & \multirow{3}{*}{2.0} & & ---- & ---- & \\
\hline 5 & & & $10 \%$ & ---- & \\
\hline 6 & & & $10 \%$ & 900 & \\
\hline
\end{tabular}

Table 7 Compressive strength of ferrocement mortar after 3, 7 and 28 days in Mpa

\begin{tabular}{ccccccc}
\hline Mix No. & 1 & 2 & 3 & 4 & 5 & 6 \\
\hline 3 days & 18.5 & 19.5 & 20.3 & 21.6 & 30.8 & 34 \\
\hline 7 days & 27.5 & 29.7 & 31.7 & 28.6 & 36.03 & 40.7 \\
\hline 28 days & 29.5 & 33.0 & 34.0 & 36.5 & 44.1 & 45 \\
\hline
\end{tabular}

\section{Construction Process}

Construction process of tested tanks passes through below steps:-

1) The steel reinforcement was prepared by their required dimensions as shown in Fig. 4. 
2) A wooden mold was manufactured and it consists of two parts. The first part was used to construct the tank base and the second part was used to construct the tank walls.

3) The tank base was cast in two steps. In the first step, the first $35 \mathrm{~mm}$ thickness of the footing was cast. After that the reinforcement was inserted in their position (in the middle of the section). In the second step, the second $35 \mathrm{~mm}$ thickness of the base was cast.

4) The second part of the wooden mold was inserted.

5) The walls were cast by plastering.

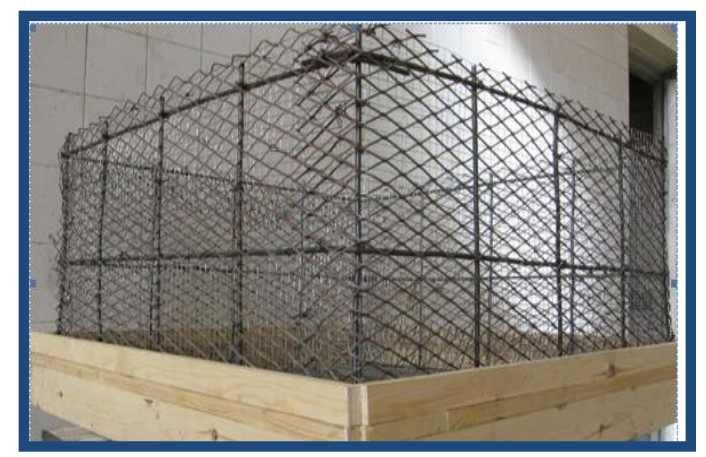

a) RT1

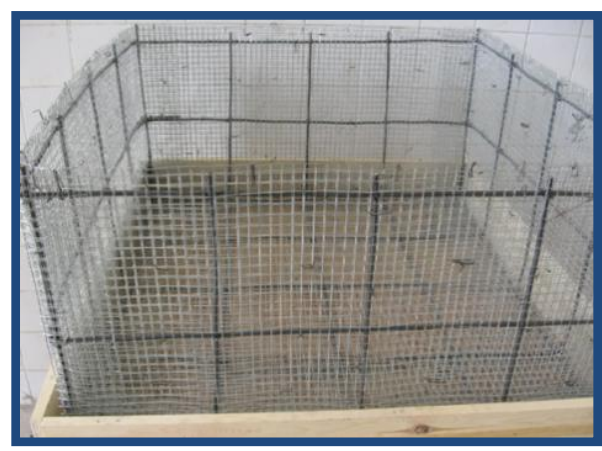

b) RT2

Fig. 4 Reinforcement systems of the tanks

The casting process of the tank was shown in Fig. 5. The specimens were stored in the laboratory atmosphere until testing after 28 days. The specimens were covered using a wet cloth, while water was sprinkled twice a day for curing. The faces of each specimen were painted in white to facilitate crack detection before the testing.

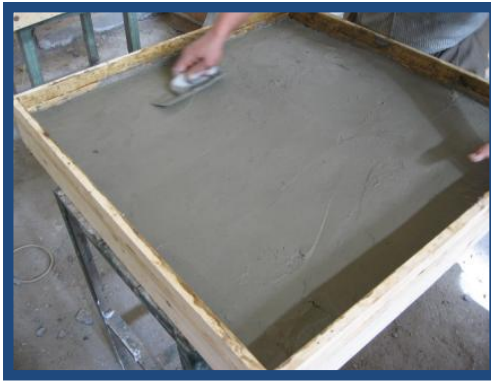

a) Casting the first layer of the base mortar

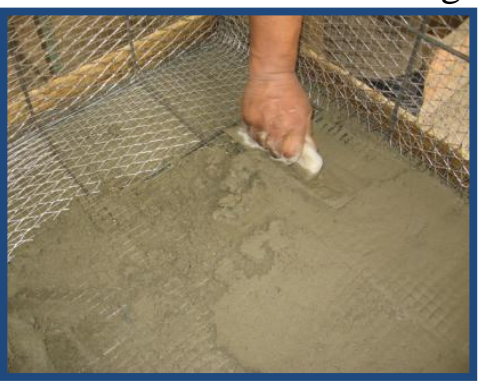

b) Casting the second layer of the base mortar

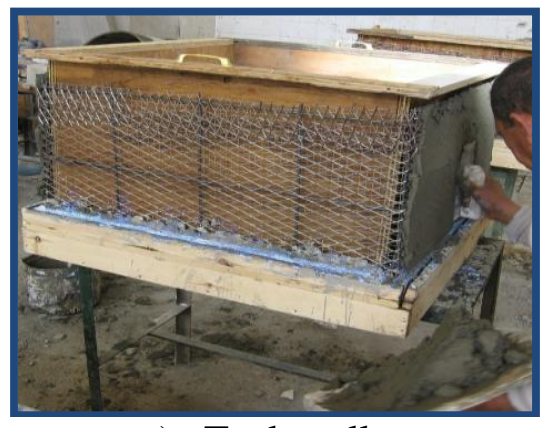

c) Tank walls

Fig. 5 Casting process of the tank

\section{Test setup}

The two tanks were tested up to failure to determine their structural performance due to static pressure loads. So that well-compacted sand was put inside the tank to study the effect of the sand pressure on the tank walls and the base of the tank. The used sand was tested to estimate the water content that was required to reach the maximum dry density of the used sand. From the test results, the water content was found to be $8 \%$. This water content was enough to give $18.5 \mathrm{kN} / \mathrm{m}^{3}$ maximum dry density. The sand was inserted inside the tank in three layers. Each layer was prepared and compacted to reach to the required maximum density (see Fig. 6). A rigid steel plate with thickness of $30 \mathrm{~mm}$ was inserted on the top surface of sand to conduct uniform load to the sand. The load was applied from a hydraulic Jake with capacity of $1000 \mathrm{kN}$ in the center point of the rigid steel plate as shown in Fig. 7. The load increment was $5 \mathrm{kN}$. To measure the horizontal deformation of tanks during test, two dials gages with an accuracy of $0.01 \mathrm{~mm}$ was used. One of them was located at $50 \mathrm{~mm}$ under the top edge of the wall and the other one was located at $50 \mathrm{~mm}$ above the tank base. 


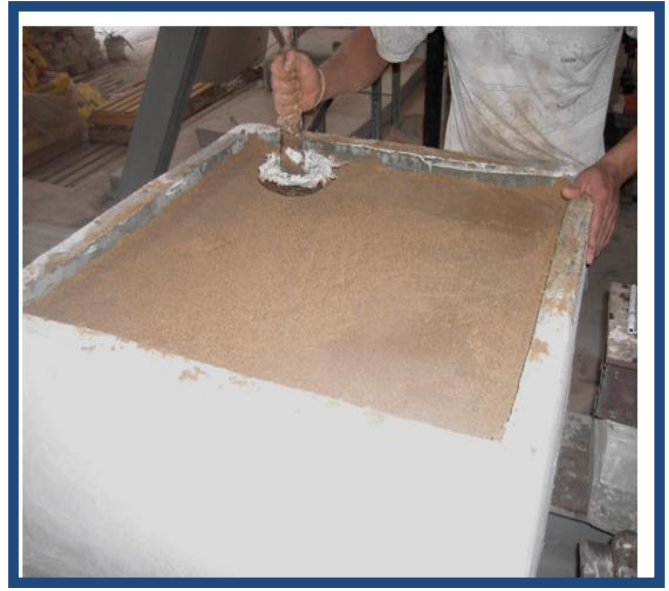

Fig. 6 Compacting the sand

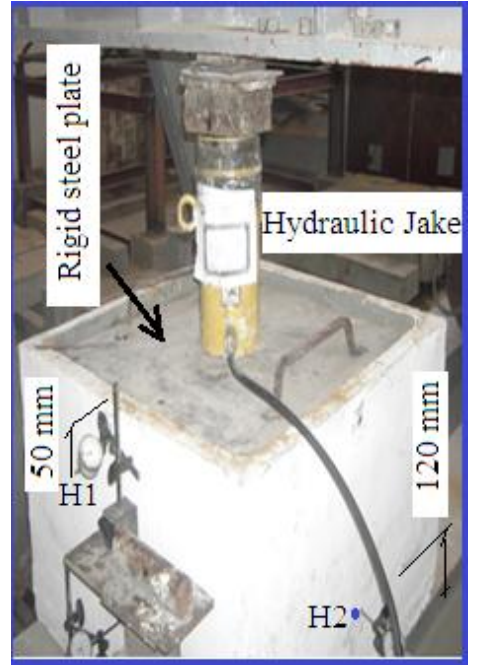

Fig. 7 Specimen test

\section{Results and Discussions}

In this section, the results of the experimental program for the ferrocement tanks are presented and discussed. Table 7 shows the experimental results of two tested tanks in tearms of first crack, and ultimate load, displacemnts at failure load and energy absorption. Energy absorption was obtained by calculating the area under the load-top horizontal displacement curve for each tank. The relationship between the applied load and the horizental displacements at $\mathrm{H} 1$ and $\mathrm{H} 2$ points for the tested tanks are presented in Fig. 8 and Fig. 9. From Table 7, Fig. 8 and Fig. 9, it can be noted that RT2 (the tank reinforced with two layers of welded wire meshes) has the highest first crack, and ultimate load and it has the maximum energy absorption. Additionally the horizental displacement increases in the second tested tank. Fig. 10 showes the crack patterns in the two tanks. From this figure, it can be noted that the developed cracks are vertical. Also the experimental work indicated that the width of the cracks increased in the first tank in comparing with the second tested tank reinforced with expanded metal mesh this could be attributted to the highest mechanical properties of welded wire mesh compared with expanded wire mesh.

Table 7 Test results

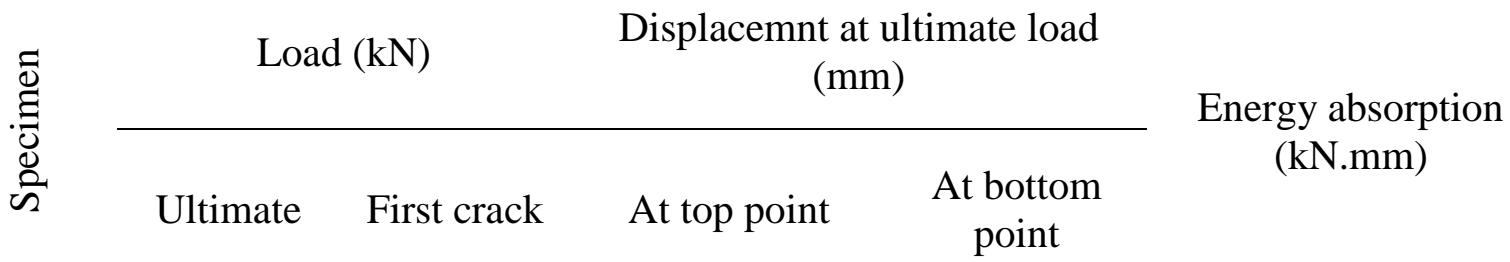

\begin{tabular}{cccccc}
\hline RT1 & 450 & 100 & 7.72 & 5.2 & 1924 \\
\hline RT2 & 650 & 250 & 19.63 & 12.24 & 9067.05 \\
\hline
\end{tabular}




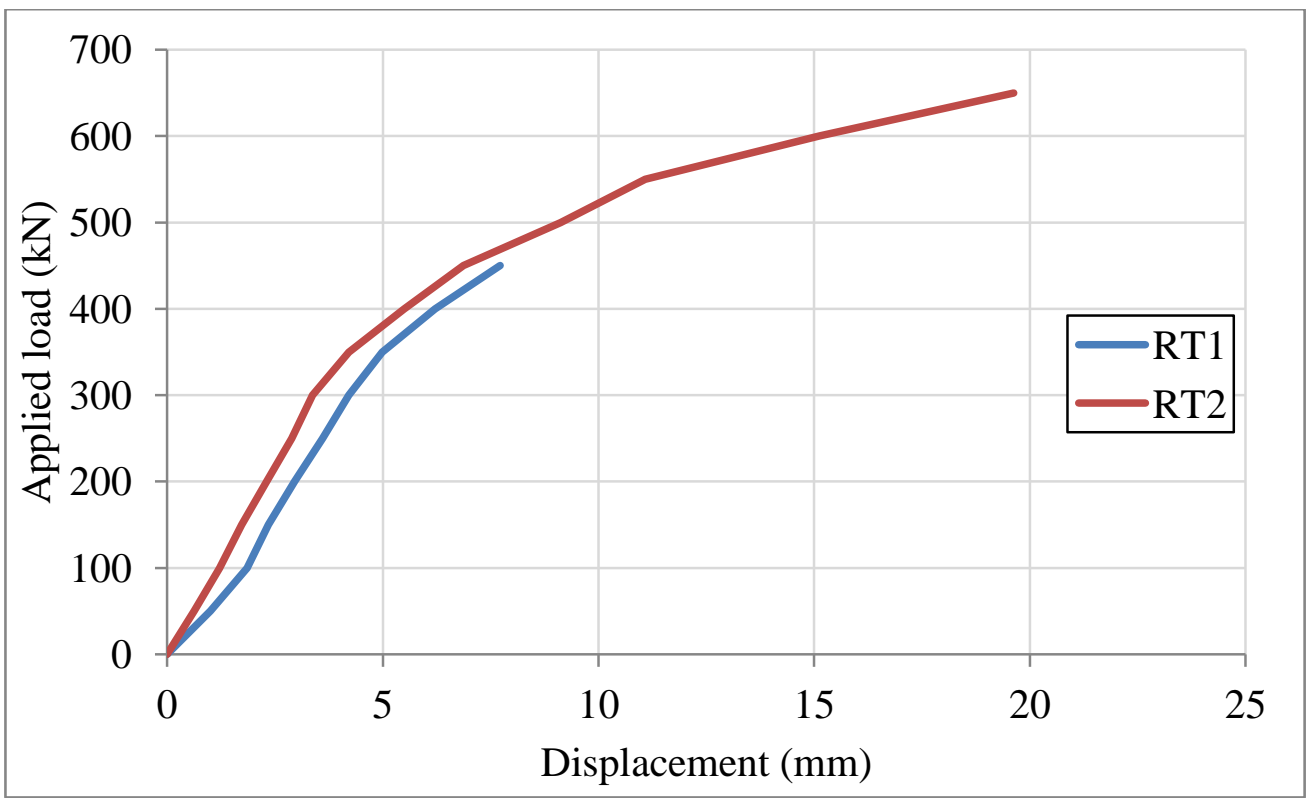

Fig. 8 Comparison between load-horizontal displacement curves obtained from the two tested tanks at top measured point (H1)

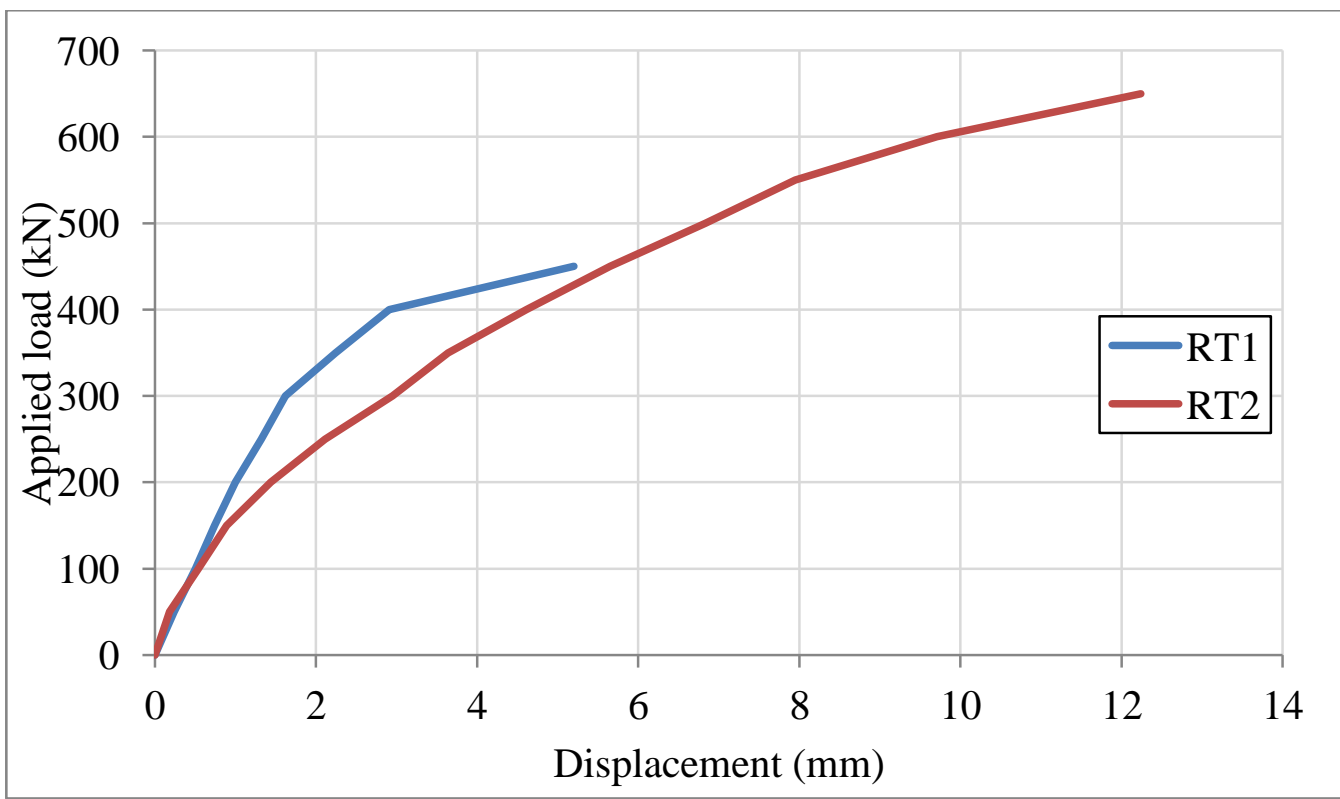

Fig. 9 Comparison between load-horizontal displacement curves obtained from the two tested tanks at bottom measured point $(\mathrm{H} 2)$ 


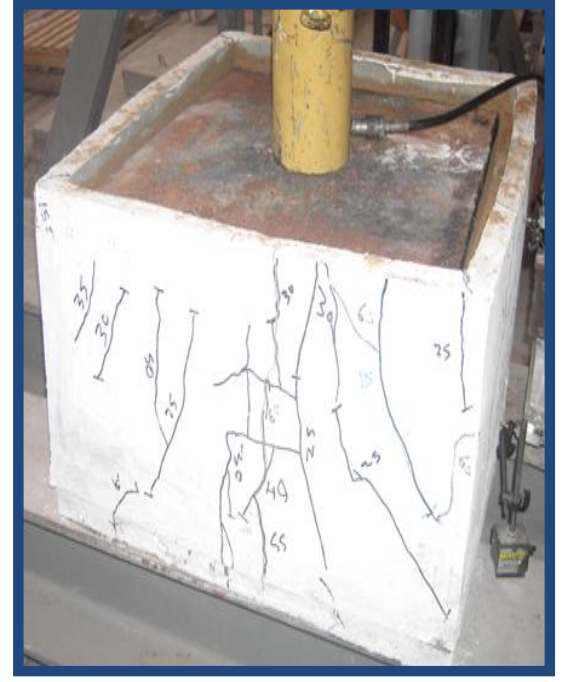

a) RT1

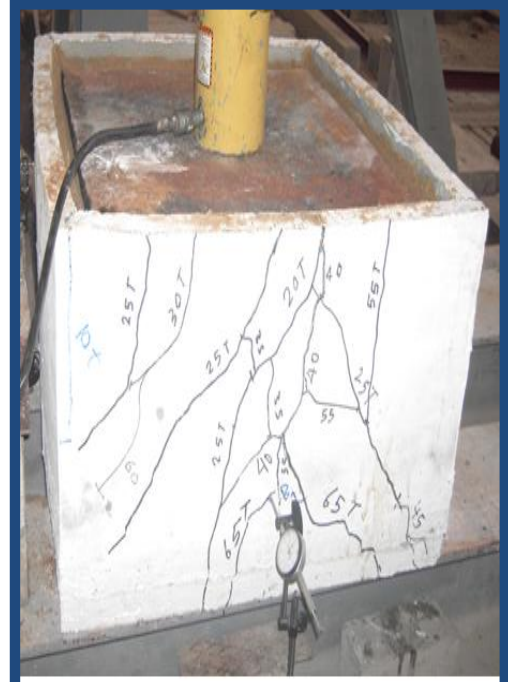

b) RT2

Fig. 10 Crack pattern of tested tanks at failure load.

\section{Conclusions}

The main objective of the current research is to investigate the structural behavior of ferrocement tank under pressure loads. In current paper, two ferrocement tanks having different reinforcements; welded and expanded wire mehes were cast and tested. From the experimental results, the following conclusions could be drawn as follows:-

1) RT2 gives first crack and ultimate load greater than RT1.

2) Using four layers of welded wire meshes in the second tested tank achieved the maximum energy absorption.

3) The cracking patterns occurred in the wall of the two tanks are vertical cracks. Also the second tank reinforced with four layers of welded wire meshes emphasized better cracking patterns compared with the first tank.

4) In general, employing welded wire mehes in reinforcement the ferrocement tank, increases the structural preformance of ferrocement tank under static pressure loads.

\section{References}

1. Aboul-Anen, B., El-Shafey, A., and El-Shami, M., "Experimental and Analytical Model of Ferrocement Slabs," International Journal of Recent Trends in Engineering, IJJCE, Oulu, Finland, 2009.

2. Ali, A., "Applications of Ferrocement as a Low Cost Construction Material in Malaysia," Journal of Ferrocement, Vol. 25, No. 2, pp. 123-128, April, 1995.

3. Al-Kubaisy, M. A., and Jumaat, M. Z., "Flexural Behavior of Reinforced Concrete Slabs with Ferrocement Tension Zone Cover," Journal of Construction and Building Materials, Vol. 14, pp. 245-252, 2000.

4. Robles-Austriaco, L., Pama, R. P., and Valls, J., "Ferrocement an Innovative Technology for Housing," Journal of Ferrocement, Vol. 11, No. 1, pp. 23-47, 1981.

5. Elavenil, S., and Chandrasekar, V., "Analysis of Reinforced Concrete Beams Strengthened with Ferrocement," International Journal of Applied Engineering Research,Vol. 2, No. 3, pp. 431-440, 2007.

6. Fahmy, E. H., Shaheen, Y. B., and Korany, Y. S., "Use of Ferrocement Laminates for Repairing Reinforced Concrete Slabs," Journal of Ferrocement, Vol. 27, No. 3, pp. 219-232, July, 1997. 
7. Jumaat, M., and Alam A., "Flexural Strengthening of Reinforced Concrete Beams Using Ferrocement Laminate with Skeletal Bars," Journal of Applied Sciences Research, Vol. 2, No. 9, pp. 559-566, 2006.

8. Kaish, M. A., Alam, A. B., Jamil, M. R., Zain, M. F., Wahed, M. A., "Improved Ferrocement Jacketing for Strengthening of Square RC Short Column," Journal of Construction and Building Materials, Vol. 36,pp. 228-237, 2012.

9. Mourad, S. M., and Shannag, M. J., "Repair and Strengthening of Reinforced Concrete Square Columns Using Ferrocement Jackets," Journal of Cement and Concrete Composites, Vol. 34, pp. 288-294, 2012.

10. Fahmy, E., Shaheen, Y., and El-Dossouki., W., "Application of Ferrocement for Constructing of Radial Gates," Journal of Ferrocement, Bankok, Thailand, Vol.25, No.2, pp. 115-121, April, 1995.

11. Xiong, G. J., Wu, X. Y., Li, F.F., and Yan, Z. "Load Carrying Capacity and Ductility of Circular Concrete Columns Confined by Ferrocement Including Steel Bars,'Journal of Construction and Building Materials, Vol. 25, pp. 2263-2268, 2011.

12. Basunbul, A. A. Gubati, G. J. Al-Sulaimani, and M. H. Baluch, "Repaired Reinforced Concrete Beams," ACI Materials Journal, No. 87-M37, pp. 348-354, July-August, 1990.

13. Naaman, A. E. and Shah, S.P., "Tensile Test of Ferrocement," ACI Journal, Proceedings, Vol. 68, No. 9, pp. 693-698, 1971.

14. Rajagoplan and V. S. Parameswaran, "Analysis of Ferrocement Beams," Journal of Structural Engineering, Vol. 2, No. 4, Jnuary, pp. 155-164, 1975.

15. Abd El-Fatah, S., "Structural Behavior of Concrete Beams Reinforced with Innovative Materials," MSc Thesis, Minufiya University, Egypt, 2014.

16. Abd-El-Naby, A., "Development of Ferrocemnt U-Shaped Beams in Filled with Core Materials," MSc Thesis, American Unversity, Egypt, 2012.

17. Shaheen, Y., Eltaly, B., and Abdul-Fataha, S., "Structural Performance of Ferrocement Beams Reinforced with Composite Materials," Structural Engineering and Mechanics, Vol. 50, No. 6, pp. 817-834, 2014.

18. Henish, A., "Design and Construction of Ferrocement Domes," MSc Thesis, Minufiya University, Egypt, 2015.

19. Shaheen, Y., Eltaly, B., and Henish, A., "Experimental and FE Simulations of Ferrocement Domes Reinforced with Composite Materials," Concrete Research Letters, Vol. 5, No. 4, pp. 873-887, 2014

20. Skinner, B., Reed, B., and S., Rod, "Ferrocement Water Tanks," Technical report, Loughborough University, UK.

21. Patel, J. K., and Sheth, M. M.., "Water tanks with ferrocement techniques," Proceedings of the Third International Symposium on Ferrocement 190-199. Roorkee: University of Roorkee, India, 1988.

22. Hanai, J. B., "ferrocement Water Tanks with Precast Barrel Vault Element," Journal of ferrocement, Vol. 1, No. 14, pp. 37-54, 1984.

23. Watt, S.B., "Ferrocement Water Tanks and their Construction," Technical Report, London, 1978.

24. Paramasivam, P., and Nathan, G. K., Prefabricated Ferrocement Water Tanks, ACI Journal, Novemeber-December, pp. 580-585, 1984.

25. Narayan, J. P., Murty, V. V. N., and Nimityongskul, P., "Ferrocement Farm Irrigation Structures," Journal of ferrocement, Vol.20, No. 01, July, 1990, pp. 11-22.

26. Mansur, M. A., "Design and Construction of Elevated Ferrocement Water Tanks," Concrete International, pp. 37-40, April, 1990.

27. Abd-Allh, M., "Study the Behavior of Ferrocement Water Tanks and Pipes," PhD Thesis, Minufiya Unversity, Egypt, 2012. 
28. Shaheen, Y., and Elsayed, A. A., "Design and Construction of Ferrocement Water Tanks," Concrete Research Letters, Vol. 4, No. 4, pp. 684-695, 2013

29. Fahmy, E. H., and Shaheen, Y. B. "Strengthening and Repairing of Reinforced Concrete Tanks", 4th Arab Structural Engineering Conference, Cairo, pp.18-21, 1991.

30. Fahmy, E., Shaheen, Y., and El-Dessouki, W., "Laminated Ferrocement for Strengthening of Reinforced Concrete Tanks," Proceeding of the 5th International Colloquium on Concrete in Developing Countries, Cairo, Egypt, January, 1994.

31. E.S.S (2011), "Egyptian Standard Specifications for Plain and Reinforcement Concrete," Egypt, No. 2070-2007. 